\title{
Testing balanced counseling to improve provider-client interaction in Guatemala's $\mathrm{MOH}$ clinics
}

\author{
Federico R. Leon \\ Carlos Brambila \\ Marisela de la Cruz \\ John H. Bratt \\ Julio Garcia Colindres
}

See next page for additional authors

Follow this and additional works at: https://knowledgecommons.popcouncil.org/departments_sbsr-rh

Part of the Demography, Population, and Ecology Commons, and the International Public Health Commons

How does access to this work benefit you? Let us know!

\section{Recommended Citation}

Leon, Federico R., Carlos Brambila, Marisela de la Cruz, John H. Bratt, Julio Garcia Colindres, Benedicto Vasquez, and Carlos Morales. 2003. "Testing balanced counseling to improve provider-client interaction in Guatemala's MOH clinics," FRONTIERS Final Report. Washington, DC: Population Council. 


\section{Authors}

Federico R. Leon, Carlos Brambila, Marisela de la Cruz, John H. Bratt, Julio Garcia Colindres, Benedicto Vasquez, and Carlos Morales 


\section{Testing Balanced Counseling to Improve Provider-Client Interaction in Guatemala's MOH Clinics}

October 2003

Federico R. León, Carlos Brambila, Marisela de la Cruz, John Bratt, Julio García Colin-dres, Benedicto Vásquez, and Carlos Morales

Population Council

Family Health International

Guatemala Ministry of Health

This study was funded by the U.S. AGENCY FOR INTERNATIONAL DEVELOPMENT (USAID) under the terms of FRONTIERS Cooperative Agreement Number HRN-A-00-9800012-00 and project number 5801 13052. The opinions expressed herein are those of the authors and do not necessarily reflect the view of USAID. 


\section{EXECUTIVE SUMMARY}

\section{Context}

The job aids-assisted Balanced Counseling Strategy developed in Peru helps providers diagnose clients' needs to improve method choice. Providers and clients sequentially discard irrelevant methods (cards). The strategy offers standard information on four attributes per method and encourages providers to concentrate the remainder of the session on explanation of a pamphlet on the method chosen by the client. Its adoption by Guatemala's Ministry of Health required more specific instructions for use by nonprofessional providers and an intervention that assured provider compliance with the behavioral requirements of the new paradigm.

\section{Methodology}

Researchers developed a 22-step service algorithm offering detailed instructions and assisted by method cards and client pamphlets. Providers from 40 health centers and posts of Quiche (Mayan) and Jutiapa (Ladino) were trained in its use and exposed to four reinforcing revisits. Forty facilities from Quetzaltenango (Mayan) and Jalapa (Ladino) only received the pamphlets. Simulated clients enacted two Service Test client profiles in each of the 80 facilities to assess the quality of care provided before and after the intervention.

\section{Results}

As many as 72 percent of the trained providers used the algorithm and job aids with the simulated clients. The quality of care increases due to training amounted to three standard deviations. The trained providers outperformed the controls in quality of care at each level of session length, but used nine extra minutes per session on average.

\section{Conclusions}

Non-professional providers can take advantage of the job aids-assisted Balanced Counseling Algorithm and substantially improve their quality of care. The extra time invested in counseling new family planning clients will be easily absorbed insofar as they continue to represent a small portion of the total demand for services at the clinics. 


\section{ACKNOWLEDGEMENTS}

The authors are indebted to Edgar Reyes, Genard Méndez, Alba Ramírez, and Maritza de Andrino for coordinating and supporting the intervention in Quiche and Jutiapa; Irma Ramos for her assistance in the training of trainers; Rosa Monge in the training of simulated clients; Jorge Solórzano and Berna Salas in the coordination with Calidad en Salud; and Orly Lam, Clara Luz Barrios, and Julio Hernández in the training of providers. The cooperation from health authorities and providers of the Quetzaltenango, Quiche, Jutiapa, and Jalapa areas is gratefully acknowledged. We also thank the supervisors, simulated clients, and administrative staff of the Population Council in Guatemala who helped implement the study. 


\section{CONTENTS}

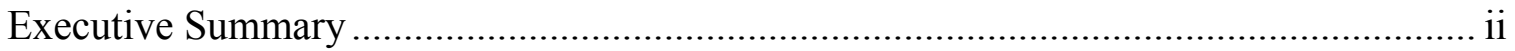

Acknowledgements ........................................................................................ ii

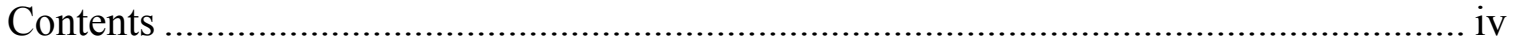

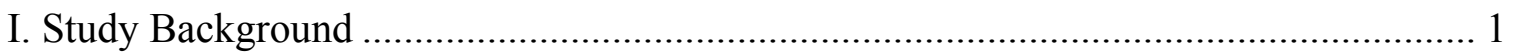

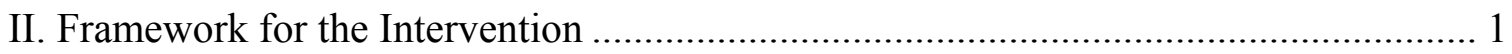

The Job Aids-assisted Balanced Counseling Strategy .................................................. 1

The Need for an Algorithm and Reinforcement ..................................................... 2

On-going Tools and Interventions ........................................................................ 3

III. Design and Conduct of the Study ………………................................................... 4

Research Design................................................................................................. 4

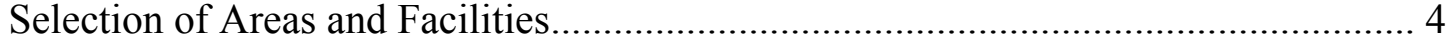

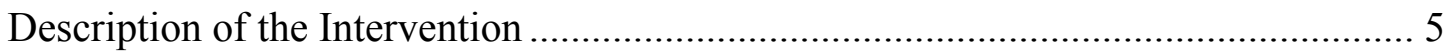

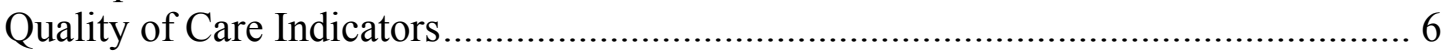

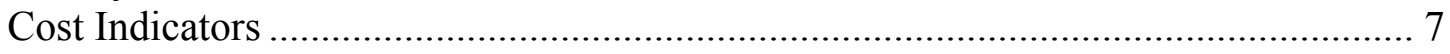

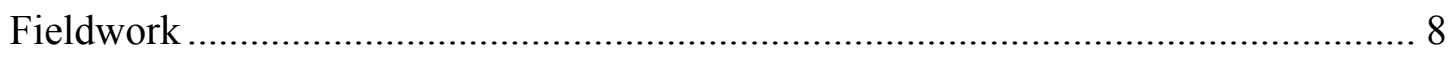

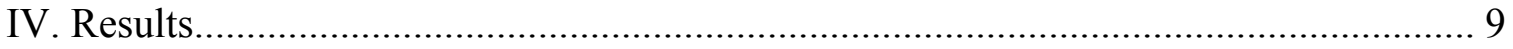

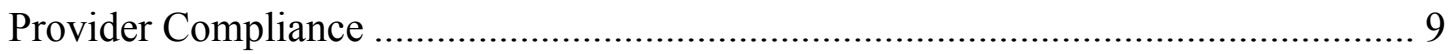

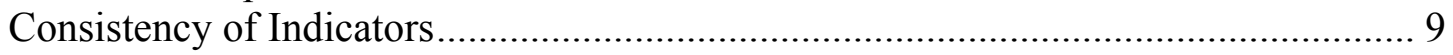

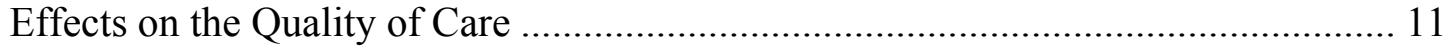

Effects on Session Length................................................................................... 12

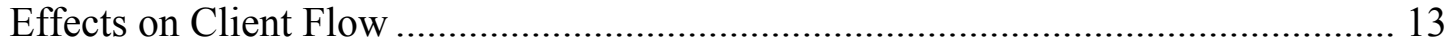

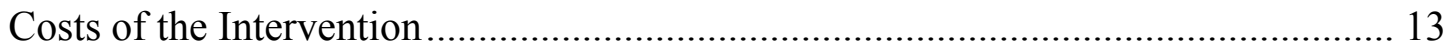

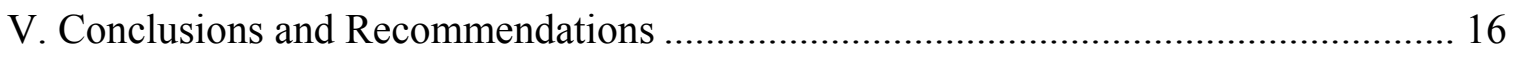

The Job Aids-Assisted Algorithm Improves the Quality of Care................................. 16

Increased Session Length Does Not Impinge on Client Flow .................................... 17

Results are Valid Across MSPAS Health Areas ........................................................ 17

Results are Valid Across Different Types of Clients................................................ 17

Further Improvements Can Be Introduced ............................................................ 17

Scaling-Up Can Be Conducted at a Lower Cost........................................................ 18

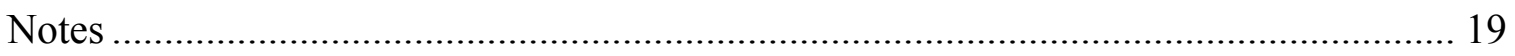

Appendix 1: Job Aids-Assisted Balanced Counseling Algorithm.................................... 21

Appendix 2: Method Cards ....................................................................................... 22

Appendix 3: Example of Method Pamphlet................................................................... 31 


\section{STUDY BACKGROUND}

Contraceptive prevalence among Guatemalan fertile-age women in union is 38.2, of which 7.2 involve traditional methods (1999). Yet national figures do not reflect internal inequalities. While the prevalence among modern-western Ladinos is 49.9, among Mayan indigenous groups it merely reaches 12.9. Place of residence makes a lesser difference (urban: 52.3 ; rural: 27.2). ${ }^{1}$

The quality of family planning care may explain, in part, this situation. In 1999, medical barriers such as the use of restrictive selection criteria, requirements of partner consent, unjustified precautions, limiting procedures, and provider bias distorted service provision and method choice. Users were not receiving enough information about the method they selected. Only 27 percent of providers informed the users on the method's side effects, 33 percent gave out pamphlets, and barely 46 percent of users received the method they desired. ${ }^{2}$ In four departments in the highlands with a majority of Mayan residents, 65 percent of providers were reluctant to offer contraceptives to adolescents, 66 percent requested partner consent as a prerequisite, and 64 percent required that women have a certain number of children before offering certain methods. ${ }^{3}$

\section{FRAMEWORK FOR THE INTERVENTION}

\section{The Job Aids-Assisted Balanced Counseling Strategy}

In late 2000 the Guatemalan Ministry of Health and Social Welfare (MSPAS) learned that the Peru MOH was successfully introducing a job aids-assisted Balanced Counseling Strategy ${ }^{4}$ that showed significant promise as a possible solution to the delivery problems identified in the diagnostic studies (Figure 1).

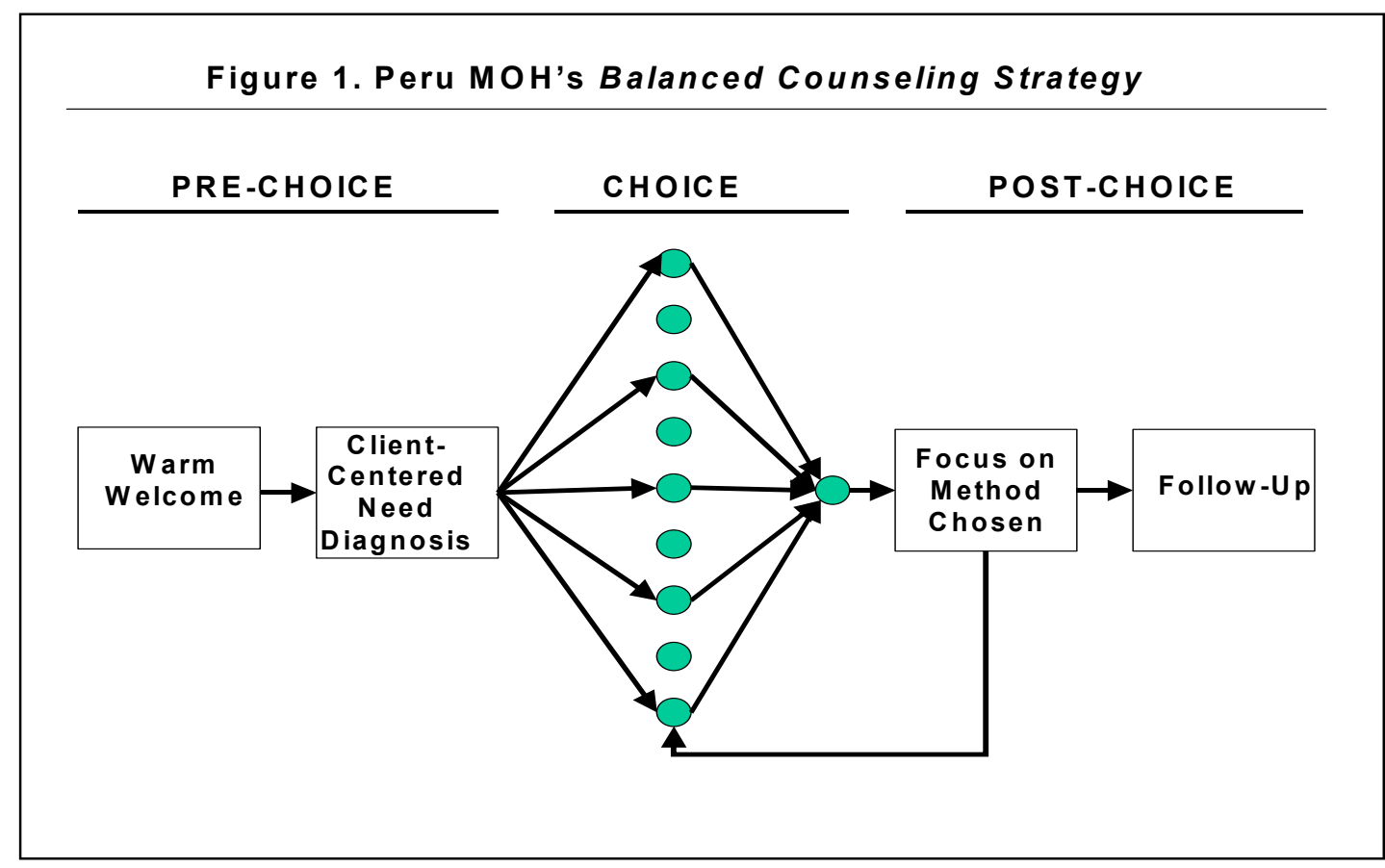

Testing Balanced Counseling to Improve Provider-Client Interaction in Guatemala's MOH Clinics 
In the pre-choice phase of the new counseling paradigm, the provider is expected to put client need diagnosis at the service of method choice by publicly discarding irrelevant methods. For instance, providers might discard tubal ligation and vasectomy if the client is a spacer, or barrier and natural methods if the client's partner does not cooperate in family planning. In the choice phase, the provider avoids client information-overload by limiting the information provided to four standard descriptors per remaining method. The post-choice phase is entirely dedicated to the method chosen by the client. If the method is contraindicated for her, or if she rejects her preliminary choice once she learns more details about the method (e.g. all the use requirements), the client can go back to the choice phase and choose an alternative method. Finally, follow-up instructions must be given so that the client knows all that is needed to proceed safely and ensure continuity in method use.

The Peru MOH used three job aids to help providers and clients in this process. One was a poster presenting the new counseling model and offering guidance to the provider step by step. The second was a set of 11 small cards, one per method. The cards have on one side the name of the method and a relevant figure and, on the back, four basic descriptors and the method's efficacy rating. The provider is expected to display the method cards on the table and discard the irrelevant methods one by one as she evaluates the client's needs. Once a method is discarded, the provider separates the card and tells the client why that method will not be discussed.

At the end of the need diagnosis phase, the cards representing the remaining methods lie on the table. The provider reads the client the four descriptions for each of the remaining methods (or lets her read them) and asks her to make a choice.

The third Peruvian job aid adopted was a set of 11 pamphlets, one per method. The fourpage pamphlets have sections on general information, contraindications, action mechanisms, benefits, use instructions, side effects, danger signs, and follow-up instructions. The provider explains to the client, "Ma'am, you are going to take this pamphlet home, but now I want to explain its contents to you," and uses the pamphlet as a checklist to screen the client for contraindications and to provide her detailed information on the method chosen. The client is not expected to perceive the pamphlet as a job aid for the provider but as an aid for herself.

\section{The Need for an Algorithm and Reinforcement}

Whereas in Peru the provider is typically a professional obstetric nurse with a university education, an overwhelming majority of MSPAS providers are auxiliary nurses. Researchers in Guatemala questioned whether the auxiliary nurses would be able to implement the strategy because of its limited instructions, or if more detailed guidance was needed. FRONTIERS staff proposed a job aids-assisted, three-phase algorithm to offer more detailed guidance to the provider and assure informed choice on the part of the client. The algorithm presented 22 steps for the provider to follow. 
Another source of concern was the finding in Peru that the intervention substantially improved the quality of care, but that only a minority of the trained providers actually implemented the strategy in their interactions with clients. This was attributed to the brevity of the training and the lack of strong reinforcement of the model. At the posttest, trained providers who did not use the method cards or pamphlets in counseling performed at the same level of quality as untrained providers. Their clients did not benefit from the innovation.

This study tested a job aids-assisted Balanced Counseling Algorithm and, to strengthen provider motivation to use the innovation with clients, placed special emphasis on reinforcing what they learned.

\section{On-Going Tools and Interventions}

The testing took place when of a number of quality-of-care models and tools were in use at MSPAS facilities. According to one of the diagnostic studies ${ }^{5}, 78$ percent of providers used a lineal flipchart in counseling sessions to help clients choose a method. Whereas this tool was available nationally, various job aids were available only in some health areas.

The programmatic context also included an encompassing intervention. In 2000, assisted by the Calidad en Salud Program, MSPAS began a national-level effort to reduce medical barriers and strengthen informed choice. In the first stage, a family planning update course was conducted for technical personnel at the MSPAS central level. The second stage consisted of orientation workshops for technical personnel from health areas, counseling courses for nurses and doctors who were heads of districts; counseling courses for hospital personnel; tutorials on voluntary surgical contraception techniques for hospital personnel; postpartum contraception in community maternity centers; and family planning updates for personnel from health districts and posts. The third stage consisted of training and supervision by Area Facilitators (one per area) in the highlands and Regional Technical Advisors in all other areas of the country (one per three areas). Finally, there was an IEC effort to introduce method pamphlets for clients.

Two aspects of the Calidad en Salud intervention were particularly relevant to the evaluation of the algorithm. First, Calidad en Salud based family planning counseling on the GATHER model ${ }^{6}$, which offers six counseling principles: greet (establish a good connection), ask (to assess client needs), tell (tailored and personalized information), help (assist client to choose a method), explain (make sure client understands), and return (prepare for continuous services). The algorithm can be seen as a more precise and standardized application of the GATHER principles.

Second, an IEC Inter-Institutional Technical Committee led by Calidad en Salud designed method pamphlets adjusted to the educational and cultural requirements of the users. The pamphlets covered two versions of the rhythm method (Billings and a standard days rule helped by a necklace ${ }^{7}$ ), lactational amenorrhea, condoms, pills, injectables, IUDs, tubal 
ligation, and vasectomy. Calidad en Salud was to distribute the pamphlets to social workers in charge of promotion in each health area and train them to use them.

\section{DESIGN AND CONDUCT OF THE STUDY}

\section{Research Design}

Two non-equivalent control group quasi-experiments with pretest and posttest were conducted. Study 1 tested the job aids-assisted Balanced Counseling Algorithm comparing two health areas in the highlands that serve primarily Mayan populations (Quiche and Quetzaltenango). Study 2 replicated Study 1, comparing two health areas in the southeast that serve primarily Spanish-speaking Ladino populations (Jutiapa and Jalapa). The assignment of health areas to the treatments was random.

Nationwide provider training on the GATHER model started in 2000 and continued throughout the testing of the algorithm. The new method pamphlets for clients were introduced, also nationwide, in 2002. Studies 1 and 2 started with a pretest that took place in October and November 2001 and were followed by provider training on the algorithm and job aids in Quiche and Jutiapa from March through July 2002. The posttest took place in August-October 2002.

Given this design, quality-of-care increases observed in the control groups could be attributed to the continuing Calidad en Salud intervention, whereas the pretest-posttest changes between experimental and control groups are interpreted as incremental effects of the job aids-assisted algorithm.

\section{Selection of Areas and Facilities}

MSPAS services are organized in health areas. Each health area has one or more hospital and is divided into districts (5-20 or more), each headed by a health center. Within each district, health posts report to the health center.

Quiche had one hospital, 19 health centers, and 95 health posts but had recently been subdivided into two health areas. To make data collection less costly, researchers focused on the southern half of Quiche. Quetzaltenango had three hospitals, 14 health centers, and 50 health posts. To ensure that the areas were comparable, the five coastal districts of Quetzaltenango were excluded from the study. In both Quetzaltenango and Quiche, seven health centers and 13 posts were selected to participate in Study 1.

Jutiapa had one hospital, 13 health centers, and 49 health posts. Jalapa had one hospital, seven health centers, and 32 health posts. In each Jutiapa and Jalapa, seven health centers and 13 health posts were selected. In both regions, sites were selected to maximize the similarity between the facilities across the health areas. Hospitals were not considered. ${ }^{8}$ 


\title{
Description of the Intervention
}

\author{
Algorithm and Job Aids \\ The original algorithm was adjusted in a three-day workshop attended by nine staff from \\ MSPAS' central level and Quiche and Jutiapa health areas. Eight method cards and one to \\ discard pregnancy were designed using the Peruvian cards as models (Appendix 2). The \\ Guatemalan cards were larger $(11.4 \times 8.3 \mathrm{~cm})$. The first side presented the method and its \\ four descriptors and efficacy rate while the back showed contraindications. The method \\ pamphlets used were those distributed by Calidad en Salud $(12.4$ x $19.3 \mathrm{~cm})$. The \\ Peruvian pamphlets included human and anatomical figures, excluded contraindications, \\ and generally contained fewer informational items (see example in Appendix 3). The \\ Guatemalan cards and pamphlets were strictly consistent with MSPAS' National \\ Reproductive Health Guidelines. ${ }^{9}$
}

\section{Training of Trainers}

Three health professionals recruited to train trainers observed the workshop and were then trained, along with the project coordinator, during a two-day session. They practiced role-playing and agreed on a training agenda for the provider training.

\section{Training of Providers}

One pair of trainers conducted the intervention in Quiche and the other in Jutiapa. Accompanied by staff from central level MSPAS, they visited each health area, made a presentation to the area authorities, and designed the training itinerary with them. Then they visited eight districts in Quiche and 17 in Jutiapa. Each training session took six hours and targeted the health center's medical director, nurse, and nurse auxiliaries, plus staff from all the dependent health posts, whether they were included in the study or not. Staff from 20 facilities in both Quiche and Jutiapa participated in these workshops. On average, there were eight participants per training session. The providers were instructed to use the algorithm and job aids with every new-event family planning user (i.e., clients who are new to family planning, changing methods, or reinitiating use of a method after six months).

\section{Provider Retraining}

The six hours employed in provider training represented only the first step of a learning program. The training team performed four revisits of variable length to each provider from the intervention facilities to train those that had been absent and reinforce everyone's learning. If the provider was with a client, the trainer observed the counseling session and gave the provider feedback later. If the provider was free, the trainer roleplayed use of the algorithm with him/her. After these revisits, the trainers reported that the providers had achieved reasonable mastery of the algorithm and job aids.

\section{Supervision Component}

In addition to the health area nurses, district level nurses were also trained in the use of the algorithm and job aids, and to monitor provider-client interactions and offer feedback to providers. The nurses were instructed to visit dependent health centers and posts and supervise use of the algorithm. Four sessions of supervisory training of four hours each 
were conducted in the provider-retraining phase. In about 15 percent of the revisits to providers the intervention team included nurses trained as supervisors.

\section{Availability of Pamphlets}

The visits also served to streamline Calidad en Salud's pamphlet distribution to the individual facilities. When a scarcity or lack of pamphlets was observed, the training team insisted the area promotional staff (of either Quiche or Jutiapa) actually make the pamphlets available to each facility. Research staff also verified that pamphlets had arrived at each control health area and encouraged the promotional staff to distribute them to the clinics, though they did not verify the availability of pamphlets at individual control facilities.

\section{Quality of Care Indicators}

\section{Service Test}

This tool, similar to the "standard patient" medical technique, ${ }^{10}$ is designed to assess typical provider behavior. Services are provided to simulated clients and the provider does not know that he/she is under observation and, hence, can be expected to show her/his typical effort. The Service Test consists of client profiles, trained simulated clients, and observational checklists.

\section{Client Profile A}

This simulated client profile depicted a healthy young woman aged 19-22 with a 10month-old child, whose husband had migrated to the United States. On his imminent return, the husband planned to work in a farm under "Plan 22," i.e., work 22 days per month and stay home the remainder of the month. The client had never used family planning but wanted to control her fertility until the family's economic status improved. She decided not to use the rhythm method (her sexual activity would be governed by Plan 22), the condom (she thought this was a method for "bad women"), the pill (she feared she would not be able to remember to take it every day), LAM (she was not breastfeeding her son), or sterilization (she wanted more children in the future). If given a choice, she would choose the DMPA injectable. When asked about her menses, she told the provider that she was between the first and seventh day of menstruation. This response was devised to show the provider that she was not pregnant and thus was apt to be injected immediately. The profile indicated that she did not know what a Pap smear was, and had not had intercourse in the past year. The simulated client was instructed to reject a pelvic exam if the provider required it, saying that she felt ashamed because of the menstruation. She stopped the counseling session and left when the provider was ready to provide the injection, saying that she now preferred to consult with her husband or her mother-in-law.

\section{Client Profile B}

This simulated client profile depicted an older woman (30-40 years old) with four children, the youngest being 2 years old. She and her husband thought that they could not afford to have a fifth child. The client had used the rhythm method, condoms, and pills and said the last three children were a result of contraceptive failures. She would not choose the injectable for fear of yet another method failure, despite any provider 
argument. She would not choose the IUD (she did not like having a device inside her body) or vasectomy (out of respect for her husband). If given a choice, she would choose tubal ligation. The profile indicated that she had had one miscarriage, but otherwise was a healthy person and did not have reason to believe that she could be pregnant. In other respects, the profile was similar to that of Client A. As the surgery would not be provided immediately, she did not need to stop the counseling session.

To present a credible client profile, the simulated client was instructed to approach the facility as a person with a health problem unrelated to family planning (e.g., a headache or another physical discomfort). Few clients in Quiche, Quetzaltenango, Jutiapa, or Jalapa go to a facility requesting family planning. As the consultation progressed, however, she found a way to suggest family planning. Only if the provider did not catch the suggestion did she explicitly request it.

\section{Checklist}

The simulated clients were trained to fill out a checklist as they left the premises. The checklist for Profile A included 65 observable provider behaviors expected in the management of a case like Client A. The Profile B checklist had 64 items. The items pertained to interpersonal relations, needs diagnosis, and method options, as well as contraindications, action mechanisms, advantages, use instructions, side effects, and danger signs of the method chosen, plus waiting time for method and follow-up.

\section{Quality of Care Scores}

Four scores were computed for each checklist by summing dichotomous item scores $(1=$ observed, $0=$ not observed). The first score, Pre-Choice QoC, encompassed the provider's initial behavior, including interpersonal relations and needs diagnosis, and included 15 items in Profile A and 14 for Profile B. The Choice QoC score evaluated the provider's offer of method options, the client's choice, and screening for contraindications. There were 27 items in Profile A and 32 in Profile B. The Post-Choice QoC score pertains to the provider's information exchange on the method chosen, including use instructions, side effects, danger signs, and follow-up. Profile A included 23 items and Profile B had 18. The total QoC Score is the sum of the three previous scores.

\section{Client Exit Interviews}

New-event family planning users were interviewed as they exited the counseling session. The interview focused on the services received and the client's knowledge concerning the method chosen.

\section{Cost Indicators}

In the design of this study researchers hypothesized that improved quality of care might be achieved at the cost of greater counseling session length and, consequently, a smaller number of clients would be served. Two cost indicators were constructed to evaluate these hypotheses. Additionally, the cost of the intervention was calculated. 


\section{Session Length}

The simulated clients learned to time session length, distinguishing between waiting time and consultation. Because typical health center and health post clients do not wear watches, the simulated clients were instructed to use the facility's clock to register the time at which the consultation began. As the consultation finished and they left the room, they would register the time again.

\section{Client Flow}

This estimate, obtained from each facility's service statistics, pertained to the average daily number of clients (women, men, and children) served during the month of data collection at the clinic.

\section{Costs of the Intervention}

The economic analysis was designed with two main purposes in mind: first, to document the incremental cost-effectiveness of the intervention to improve quality of care; and second, to provide information to MSPAS executives on the costs of replicating the intervention in other areas of the country. Three phases of the intervention process were identified. The design phase consisted of the three-day workshop at which FRONTIERS and MSPAS staff discussed the content of the intervention and developed curriculum for the training sessions. The implementation phase included the meetings to present the counseling model to participating providers, the training of trainers workshop, and the two workshops to train MSPAS providers in the use of the counseling model. During the supervision phase, project staff followed up with providers over a three-month period to assess their performance and to provide feedback and reinforcement.

Customized spreadsheets were used to collect information on the various inputs (i.e., labor, materials and capital) used in each phase of the intervention. Researchers identified the inputs, measured the quantity of each input used, assigned a unit cost to each input, and calculated total cost by multiplying the quantity used by the unit cost. Inputs were also classified as financial (those requiring an actual payment by FRONTIERS) and nonfinancial (resources which had already been purchased but were redirected to the intervention). Costs of the three phases were summed to find the total cost of the intervention.

\section{Fieldwork}

\section{Subject Consent}

The research team visited the 80 facilities selected for the study and solicited each provider's consent to participate in the research, including authorization to observe them through simulated clients. Informed consent was obtained from clients prior to the exit interviews.

\section{Service Test}

For the pretest, eight candidates were selected to work as simulated clients in Quiche and Quetzaltenango from a pool of 20. The candidates, who were trained in Quetzaltenango, belonged to the local cultures and spoke at least one of the Mayan languages. Training 
took five days on average. Four of them learned Client Profile A and four learned Client

Profile B. Each simulated client candidate had the opportunity to perform a one-day field test in actual facilities not included in the sample. Half of the candidates were then selected. Escorted at a distance by a supervisor, teams of one Profile A client and one Profile B client visited 10 facilities in Quiche and Quetzaltenango. The pairs visited the same facilities at different hours of the same day, with few exceptions, and received services from the provider that was available at the time. The teams then switched sites to conduct the visits at the other 10 facilities selected in each region. A similar process was followed in Jutiapa and Jalapa, except that the training was held in Guatemala City and required only four days, on average. For the posttest, new pools of simulated clients were tapped in each region.

\section{Client Exit Interviews}

The research team supervisor filtered all the women exiting a consultation and interviewed the new-event users. She stayed one entire shift at the facility and did not mention that the simulated clients were present.

\section{Number of Clients}

The supervisors returned to the clinics a number of weeks after the visits by the simulated clients and revised the service statistics to obtain client flow data pertaining to the month of the visits.

\section{Costs of the Intervention}

Data on the expenses associated with the activities (e.g. payments to trainers, others) and opportunity costs of the participation of service staff were obtained, respectively, from project accounting and MSPAS.

\section{RESULTS}

\section{Provider Compliance}

According to the posttest reports from the simulated clients, 72 percent of the experimental providers used all of the algorithm's job aids in counseling. This is considerably better than the 37 percent of the trained Peruvian providers who used the strategy's job aids, ${ }^{11}$ and suggests that the four revisits to providers to reinforce learning improved provider performance. An important reason for which providers did not use the job aids was the unavailability of method pamphlets at the facilities. As many as 85 percent of the providers used the method cards where they were available.

\section{Consistency of Indicators}

The average session length involving Client Profile A ranged from six minutes in the Jutiapa pretest to 23 minutes in the Quiche posttest, while that involving Profile B ranged from five minutes in the Jutiapa pretest to 28 minutes in the Quiche posttest. The differences in session length were associated with extant inequalities between the health 
areas and the effects of training, rather than different time requirements for the two profiles.

Table 1 presents the inter-correlations between the various quality of care indicators based on the Service Test. The unit of analysis was the clinic. The maximum possible number of cases was 20 clinics $\mathrm{x}$ four health areas $\mathrm{x}$ two measurement occasions (pretest, posttest). The actual number of cases ranged from133-137 due to the closing of facilities during the project life.

The Same-Profile correlations between the pre-choice, choice, and post-choice measures were all positive, large, and significant, ranging from 0.64-0.87. The part-total correlations, ranging from $0.78-0.97$, justified exclusive use of the total quality of care score.

The correlations for different profiles were lower, ranging from $0.58-0.78$ in the diagonal and from $0.52-0.77$ off the diagonal. This can be attributed in part to the possible withincorrelation variability of subjects: whereas in the same-profile correlations each pair of scores pertained to the same provider, the simulated clients enacting Profiles A and B could have been served by different providers. ${ }^{12}$ Another possible source of variability was the difference between the profiles themselves. Nonetheless, the total score correlation between the two profiles $(r=0.78)$ was high enough to justify averaging the two profiles and having a single Service Test indicator for the sake of simplifying the decision-making based on the study findings.

\section{Table 1. Pearson Correlations Between Quality of Care Indicators}

Service Test Profiles

Service Test Components

\begin{tabular}{lcccc}
\hline & Pre-Choice & Choice & Post-Choice & Total \\
& & & & \\
Same Profile & & & & \\
$\quad$ Pre-Choice & 1.00 & 0.71 & 0.68 & 0.79 \\
$\quad$ Choice & 0.66 & 1.00 & 0.87 & 0.96 \\
$\quad$ Post-Choice & 0.64 & 0.82 & 1.00 & 0.96 \\
$\quad$ Total & 0.78 & 0.97 & 0.92 & 1.00 \\
Different Profile & & & & \\
$\quad$ Pre-Choice & 0.58 & 0.59 & 0.56 & 0.63 \\
$\quad$ Choice & 0.52 & 0.75 & 0.66 & 0.75 \\
$\quad$ Post-Choice & 0.54 & 0.74 & 0.69 & 0.75 \\
Total & 0.58 & 0.77 & 0.70 & 0.78 \\
\hline
\end{tabular}

Note: All the correlations were significant at $p<0.000$, two-tailed.

\footnotetext{
${ }^{1}$ The triangle of coefficients above the diagonal presents correlations between Profile A indicators (Depo-Provera choice) whereas the triangle below the diagonal shows the correlations between Profile B indicators (Tubal ligation choice). The diagonal contains $1.00 \mathrm{~s}$ because these coefficients correspond to the correlation between the indicator and itself.

${ }^{2}$ This set of coefficients refers to the correlations between Profile A and Profile B indicators. Here, the diagonal contains coefficients pertaining to the parallel indicators (e.g., Choice from Profile A with Choice from Profile B).
} 
The client interviews only yielded 28 cases in the pretest and 33 in the posttest. Because the reliability of the results would be seriously compromised by using such small numbers of cases, these were discarded from the analyses.

\section{Effects on the Quality of Care}

Figure 2 compares the results from Study 1 and Study 2. Although the quality of care was somewhat higher in the highlands than in the southeast, the trends were nearly identical. In both studies, the change for the experimental group was considerably greater than that for the control group.

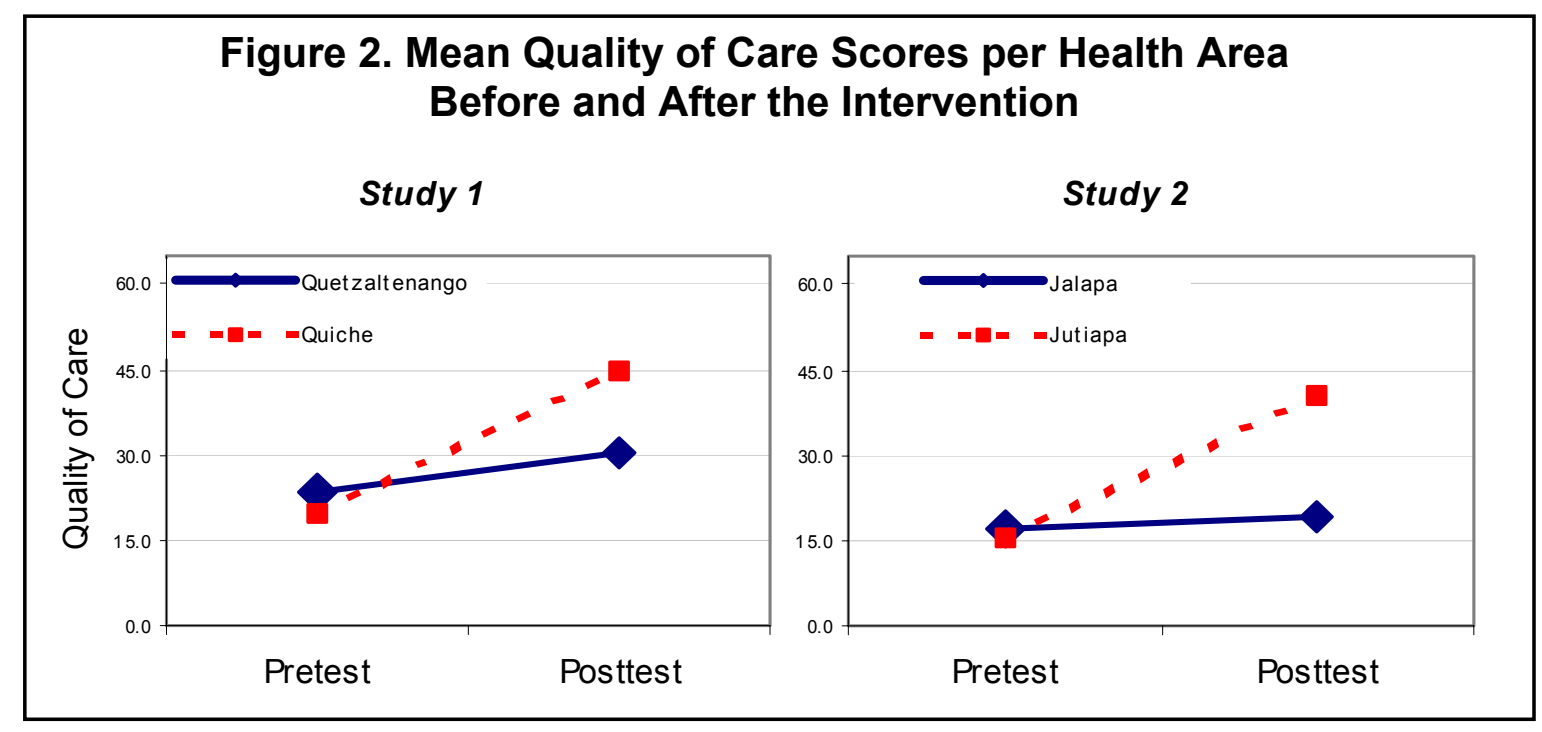

To assess the effects of the intervention maximizing parsimony and reliability, Study 1 and Study 2 were integrated. An integrated experimental group was formed combining the Quiche and Jutiapa data, and Quetzaltenango and Jalapa formed an integrated control group. The simplest analysis for a nonequivalent control group quasi-experiment with pretest and posttest is the comparison of gain scores. ${ }^{13}$ Hence, a posttest minus pretest difference in quality of care was calculated for each clinic and submitted to a $t$-test for differences in means between independent samples. Similar operations were conducted for the session length in minutes and the average daily number of clients served by the facilities. Table 2 presents the results.

The quality of care means increased from 20.2 to 24.4 in the control group and from 17.7 to 42.8 in the experimental group. The difference between the average gains was significant beyond $p<0.01$, one-tailed. The associated effect size expresses the difference between the experimental $\left(\Delta_{\mathrm{e}}\right)$ and control mean gains $\left(\Delta_{\mathrm{c}}\right)$ in pooled standard deviation units. In the calculation of the effect size, the difference between the means $\left(\Delta_{\mathrm{e}}\right.$ $\left.-\Delta_{\mathrm{c}}\right)$ is divided by $\left(\left[\mathrm{s}_{\mathrm{e}}{ }^{2}+\mathrm{s}_{\mathrm{c}}{ }^{2}\right] / 2\right)^{1 / 2}$, where $\mathrm{s}$ is in this case the sample standard deviation for the gains. ${ }^{14}$

The intervention improved the quality of care by exactly three standard deviations. ${ }^{15}$ In 
the Peru study the results suggested that three standard-unit improvements in quality of care were needed to achieve a significant one-unit increase in client's knowledge concerning the method chosen. ${ }^{16}$

Table 2. Effects of the Intervention on Quality of Care, Session Length, and Client Flow

Control Group ${ }^{1}$

Dependent Measures

Quality of Care

Session Length

Client Flow

$\begin{array}{cc}\begin{array}{c}\text { Number of } \\ \text { Clinics }\end{array} & \begin{array}{c}\text { Mean } \\ \text { Change }\end{array} \\ 34 & 4.20 \\ 35 & 1 ' 56 \text { ' } \\ 37 & 4.54\end{array}$

Treatment Group ${ }^{2}$

\section{Number of} Clinics

29
32
34

Effect Size

Change

$\begin{array}{cc}25.14 & 3.00^{* *} \\ 10{ }^{\prime} 58^{\prime} & 0.85^{*} \\ 3.02 & -0.07\end{array}$

Note: Only clinics having pretest and posttest measurements entered in the calculations. The variability in sample sizes is due to the loss of clinics or the lack of measurements. The $p$ levels denoted by the asterisks are those of the corresponding $t$-test.

1 Quetzaltenango plus Jalapa.

2 Quiche plus Jutiapa.

$* p<0.005$, one-tailed.

** $p<0.000$, one-tailed.

\section{Effects on Session Length}

Counseling session length increased from $12^{\prime} 12^{\prime \prime}$ to $14^{\prime} 08^{\prime \prime}$ in the control group and from 13 ' $18^{\prime \prime}$ to $24^{\prime} 16^{\prime \prime}$ in the experimental group. The difference between mean gains was significant, but the effect size was below one standard deviation (see Table 2). ${ }^{17}$

The quality of care improvements attributed to the algorithm were observed at any level of session length. In Figure 3 the posttest of the experimental group (trained providers) is

\section{Figure 3. Mean Service Test Scores for Trained and Untrained Providers per Level of Session Length, and Percentage Distribution of Cases}

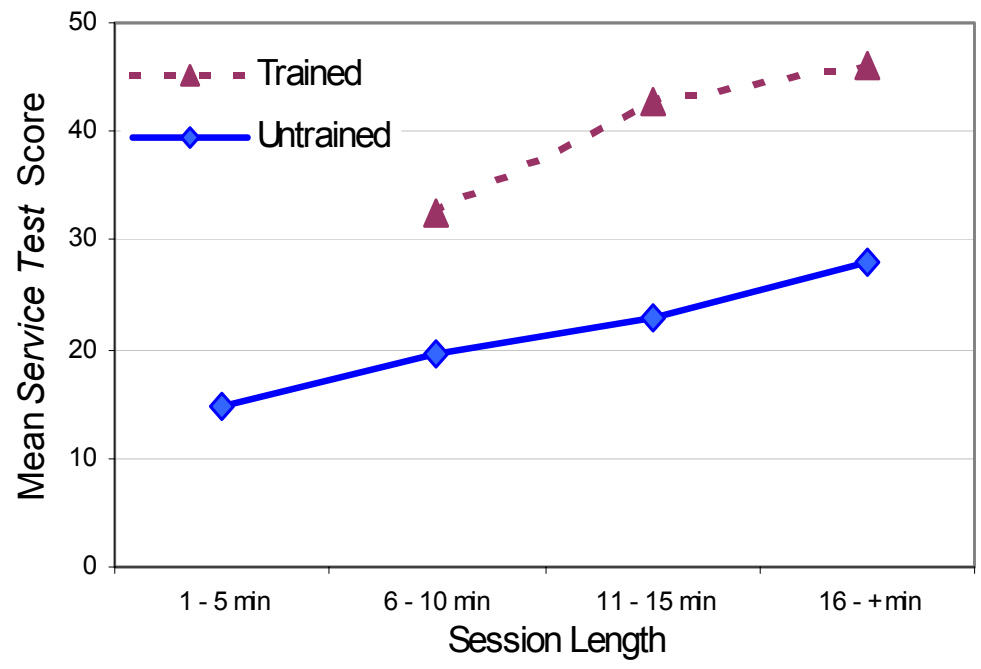

Percentage

Trained

Untrained

28

58
0
25

13
30

21

Testing Balanced Counseling to Improve Provider-Client Interaction in Guatemala's MOH Clinics 
compared with the combined experimental group pretest and control group pretest and posttest (untrained providers).

Both curves show quality of care increases associated with greater session length, yet the providers who used the algorithm present consistently higher quality of care levels. Whereas 25 percent of the untrained providers interacting with the simulated clients spent less than five minutes per session, the curve for the algorithm lacks cases with session lengths below five minutes. At the other extreme of the curves, in 58 percent of the cases using the algorithm providers invested more than 15 minutes per session, whereas only 21 percent in the comparison group did so. While providers using the algorithm outperformed the untrained providers in quality of care at any session length, they spent more time per session on average (see Table 2).

\section{Effects on Client Flow}

To obtain an average daily number of clients for each clinic (A), researchers computed A $=\mathrm{N} / \mathrm{D}$, where $\mathrm{N}$ is the number of clients served by the clinic during the month of the simulated client visits and $\mathrm{D}$ is the number of working days during the month. To obtain the means for each group, the As for a given group were aggregated and divided by the number of clinics in that group. Daily client flow increased from 21.5 in the pretest to 27.6 in the posttest in the control group and from 30.9 in the pretest to 33.9 in the posttest in the experimental group. These results reveal important differences between the experimental and control groups at the baseline and thus confirm that the assumption of nonequivalence between the groups was an appropriate criterion for selecting the research design of this study.

The differences between the changes are presented in Table 2. The increase in the number of clients from pretest to posttest suggests a seasonal trend. Alternatively, it could be an effect of the Calidad en Salud intervention. The change was greater for the control than the experimental group, but the $t$-ratio computed for the changes was not significant.

\section{Costs of the Intervention}

\section{Total Costs}

Table 3 provides information on the total costs of the intervention in the two regions. Financial costs refer to actual expenditures by the FRONTIERS program to purchase staff and consultant time, materials and supplies, and other expenses including meals and snacks provided at meetings and workshops. If MSPAS were to replicate the entire intervention in exactly the same manner, these are the costs they would incur. Nonfinancial costs are resources that MSPAS had already purchased but transferred from other service delivery operations in order to support the intervention. For example, when MSPAS providers attended the workshops MSPAS' costs did not change because their providers are all salaried workers. But the total cost of the intervention included the opportunity cost associated with providers attending workshops rather than providing services in the clinic. Total costs and the cost of each phase of the intervention were 
higher in Jutiapa than in Quiche, even though fewer providers were trained in Jutiapa (58 versus 77 , respectively).

Table 3. Costs of the Intervention to Improve Counseling in Two Regions of the MSPAS (in Guatemalan Quetzales)

\begin{tabular}{|c|c|c|c|c|}
\hline Quiche Region & $\begin{array}{c}\text { Plan / } \\
\text { Design } \\
\text { Intervention }\end{array}$ & $\begin{array}{c}\text { Implementation } \\
\text { of } \\
\text { Training }\end{array}$ & $\begin{array}{c}\text { Supervision } \\
\text { of } \\
\text { Trainees }\end{array}$ & Total \\
\hline \multicolumn{5}{|l|}{ Financial Costs } \\
\hline $\begin{array}{l}\text { Project Staff } \\
\text { (FRONTIERS staff, } \\
\text { consultants) }\end{array}$ & 6,658 & 14,502 & 124,193 & 145,353 \\
\hline $\begin{array}{l}\text { Administrative } \\
\text { Support } \\
\text { (FRONTIERS) }\end{array}$ & 750 & 150 & 0 & 900 \\
\hline $\begin{array}{l}\text { Materials and } \\
\text { Supplies }\end{array}$ & 956 & 1,857 & 0 & 2,813 \\
\hline $\begin{array}{l}\text { Meals and Venue } \\
\text { Expenses }\end{array}$ & 5,896 & 3,863 & 675 & 10,434 \\
\hline Total Financial Costs & Q.14,260 & Q.20,372 & Q.124,868 & Q.159,500 \\
\hline \multicolumn{5}{|l|}{ Non-financial Costs } \\
\hline $\begin{array}{l}\text { MSPAS Staff } \\
\text { (designers, trainees } \\
\text { and supervisors) }\end{array}$ & 4,550 & 16,104 & 12,533 & 33,187 \\
\hline Total Economic Costs & Q.18,810 & Q.36,476 & Q.137,401 & Q.192,687 \\
\hline \multicolumn{5}{|l|}{ Jutiapa Region } \\
\hline \multicolumn{5}{|l|}{ Financial Costs } \\
\hline $\begin{array}{l}\text { Project Staff } \\
\text { (FRONTIERS staff, } \\
\text { consultants) }\end{array}$ & 6,658 & 18,043 & 162,077 & 186,779 \\
\hline $\begin{array}{l}\text { Administrative } \\
\text { Support } \\
\text { (FRONTIERS) }\end{array}$ & 750 & 150 & 0 & 900 \\
\hline $\begin{array}{l}\text { Materials and } \\
\text { Supplies }\end{array}$ & 956 & 1,553 & 0 & 2,508 \\
\hline $\begin{array}{l}\text { Meals and Venue } \\
\text { Expenses }\end{array}$ & 5,896 & 5,142 & 2,292 & 13,330 \\
\hline Total Financial Costs & Q.14,260 & Q.24,888 & Q.164,369 & Q.203,517 \\
\hline \multicolumn{5}{|l|}{ Non-financial Costs } \\
\hline $\begin{array}{l}\text { MSPAS Staff } \\
\text { (designers, trainees } \\
\text { and supervisors) }\end{array}$ & 4,550 & 17,389 & 22,749 & 44,688 \\
\hline Total Economic Costs & Q.18,810 & Q.42,277 & Q.187,118 & $\underline{0.248,205}$ \\
\hline
\end{tabular}




\section{Specific Costs}

The main reason for the overall difference in costs was the cost of trainee supervision. These expenses accounted for 71 percent of total economic costs in Quiche, and 75 percent of total economic costs in Jutiapa. Supervision costs included two components. First, each trained provider received approximately two person-days of individual evaluation and feedback from members of the FRONTIERS training team. Higher per diem and transport costs in Jutiapa largely explain the differences in this component of the supervision costs because the total number of FRONTIERS person-days was the same in both regions. The second component of the supervision costs was the workshop to train nurses from health districts to offer feedback on the use of the algorithm. Attendance at the Jutiapa workshop was substantially higher than at the Quiche workshop, resulting in higher financial and non-financial costs.

Additional cost-output indicators that can be calculated are the cost per facility and the cost per trained provider. The study included 20 facilities in each health area (seven health centers and 13 posts) and so a rough estimate of the cost per facility was obtained by dividing the total cost in each area by 20. In Quiche the cost was Q.9,634 (US\$1,244) per facility, and in Jutiapa the cost per facility was Q.12,410 (US\$1,601). Jutiapa had higher overall costs while training fewer providers, and so the cost difference is even wider when costs are calculated on a per-provider basis. In Quiche the average cost per provider was Q.2,502 (US\$323), while in Jutiapa the average cost was Q.4,279 (US\$552).

\section{Cost of Replicating the Intervention in other Health Regions}

If MSPAS decided to scale up the intervention and replicate the training in other health regions some of the costs would be similar to those incurred during the OR study, but there would also be some differences. For example, it would not be necessary to repeat the three-day workshop at the beginning of the OR study, where the algorithm was developed and other aspects of the intervention were planned. Any minor adjustments to the algorithm could be made at an initial meeting in the health region when the project is introduced to local MSPAS authorities. Likewise, costs of supervision would probably be much lower in the replication, especially if MSPAS were able to identify local staff to supervise providers to avoid the high transport and per diem costs incurred during the OR study. But other costs, such as training of trainers and provider workshops, would be similar to those incurred in the study. Table 4 presents estimated costs of replicating the intervention in one MSPAS health region. The health region is assumed to have 10 health centers with an average of seven staff each and 50 health posts with one staff person each, for a total of 120 providers eligible to receive training. The average salary of MSPAS staff working at these facilities is Q.25 per hour, based on the average salary observed in Quiche and Jutiapa. 
Table 4. Estimated Costs of Replicating MSPAS Intervention to Improve Counseling (in Guatemalan Quetzales)

\begin{tabular}{|l|c|c|c|c|}
\hline Cost Items & \multicolumn{1}{|c|}{$\begin{array}{c}\text { Plan / } \\
\text { Design } \\
\text { Intervention }\end{array}$} & $\begin{array}{c}\text { Implementation } \\
\text { of Training }\end{array}$ & $\begin{array}{c}\text { Supervision } \\
\text { of } \\
\text { Trainees }\end{array}$ & Total \\
\hline Financial Costs & \multicolumn{5}{|l|}{} & \\
\hline $\begin{array}{l}\text { Project Staff } \\
\text { (FRONTIERS staff, } \\
\text { consultants) }\end{array}$ & 904 & 27,780 & 67,100 & 95,784 \\
\hline $\begin{array}{l}\text { Administrative Staff } \\
\text { (FRONTIERS support) }\end{array}$ & 0 & 150 & 0 & 150 \\
\hline Materials and Supplies & 160 & 2,565 & 0 & 2,725 \\
\hline $\begin{array}{l}\text { Meals and Venue } \\
\text { Expenses }\end{array}$ & 470 & 5,136 & 0 & 5,606 \\
\hline Total Financial Costs & $\mathbf{1 , 5 3 4}$ & $\mathbf{3 5 , 6 3 1}$ & $\mathbf{6 7 , 1 0 0}$ & $\mathbf{1 0 4 , 2 6 5}$ \\
\hline Non-financial Costs & \multicolumn{5}{|l}{} & \\
\hline $\begin{array}{l}\text { MSPAS Staff } \\
\text { (executive oversight, } \\
\text { trainees and } \\
\text { administrative support) }\end{array}$ & $\mathbf{9 0 4}$ & $\mathbf{2 0 , 1 3 9}$ & $\mathbf{2 4 , 4 0 0}$ & $\mathbf{4 5 , 4 4 3}$ \\
\hline Total Economic Costs & $\mathbf{2 , 4 3 8}$ & $\mathbf{5 5 , 7 7 0}$ & $\mathbf{9 1 , 5 0 0}$ & $\mathbf{1 4 9 , 7 0 8}$ \\
\hline
\end{tabular}

\section{CONCLUSIONS AND RECOMMENDATIONS}

\section{The Job Aids-Assisted Algorithm Improves the Quality of Care}

Non-professional providers can take advantage of the job aids-assisted Balanced Counseling Algorithm and substantially improve their quality of care. In this study, in which 71 percent of the trained providers were auxiliary nurses, training on the algorithm increased the providers' quality of care by three standard deviations. The results can be attributed to the counseling model and tools streamlined to meet providers' needs, in combination with the intensive retraining component to increase provider confidence and competence in implementing the new service paradigm in their daily interactions with clients. As many as 85 percent of the trained providers used the algorithm and method cards with simulated clients.

Confidence in the validity of these conclusions is based on the rigorous research design and the level of reliability shown by the Service Test. Observations of the pre-choice, choice, and post-choice phases of individual counseling were highly inter-correlated, as were the observations provided by the two simulated client profiles enacted $(r=0.78)$. 


\section{Increased Session Length Does Not Impinge on Client Flow}

The trained providers outperformed the controls in quality of care at each session length (e.g., sessions lasting 6-10 minutes as well as in those lasting 11-15 minutes) but used nine extra minutes per session on average. This cost of quality of care improvement, however, did not have negative effects on client flow at the clinics. The difference between experimental and control groups in changes in client flow was non-significant, presumably because of the low demand for family planning services in Guatemalan clinics. Of about 30 clients serviced at a typical health center or post per day, at best one is a new family planning client. Furthermore, some providers are not fully occupied with service and administrative functions during their entire shift. Hence, there is often enough time to accommodate the extra nine minutes invested by the trained providers per new family planning client without disrupting client flow. This cost, nonetheless, may become an issue for MSPAS if the number of new family planning clients substantially increases in Guatemala's clinics, as MSPAS hopes it will. In this event, spending extra time with new family planning users could become an obstacle to providers attending to other clients. On the other hand, providers may learn to save time as they gain more experience with the model and job aids.

\section{Results Are Valid Across MSPAS Health Areas}

The gains in quality of care were significantly greater in Quiche (intervention) than in Quetzaltenango (control) and in Jutiapa (intervention) compared to Jalapa (control) (see Figure 2). Nearly identical results occurred in Study 1 and Study 2, despite the fact that quality of care was somewhat higher in the highlands than in the southeast. Since the two regions represent the geographic and cultural diversity within Guatemala, the results have considerable external validity and can be generalized across MSPAS health areas.

\section{Results Are Valid Across Different Types of Clients}

Researchers attempted to generate two widely different simulated client profiles in order to fully represent the diverse range of Guatemalan clients. Yet, the study findings suggested that client type is a weak determinant of either the quality of care or session length. Factors other than the characteristics of the clients, such as the nature of the health area or the effects of training, bear more strongly on these dependent variables. Because the situational differences in quality of care and session length are much wider than the differences between client types, the findings can be generalized to a wide diversity of real clients with little variability.

\section{Further Improvements Can Be Introduced}

This, of course, does not signify that the algorithm has solved all the counseling problems found in Guatemalan clinics. After receiving training, the providers only averaged 50 percent of the maximum score on the Service Test, and large individual differences in quality were observed. Quality of care could still be improved if method pamphlets were made available at the clinics on a continuous basis, if providers used the method cards 
and pamphlets in 100 percent of their consultations, and if the algorithm and job aids were improved and expanded. Indeed, providers reported problems following the algorithm's instructions. Difficulties reported included method stock, referrals, and the contraindication sections of the method cards, which were regarded as complexly worded.

The algorithm could also be adapted for other client populations, such as family planning continuers and adolescents, and incorporate connections with other reproductive health topics. In the administrative realm, the supervisory function could be expanded to more systematically encompass quality of care monitoring, feedback and reinforcement for the provider, with specific reference to the Balanced Counseling Algorithm. Still, too much supervisory time is dedicated to purely administrative functions.

\section{Scaling-Up Can Be Conducted at a Lower Cost}

Expanding the intervention to other health areas could probably be done at a lower cost than was measured in the OR study. The trainers could be paid less than the consultants hired by FRONTIERS if they were contracted by a national, rather than an international, organization. The projection presented in Table 4 assumes that they earn Q.50 per hour, and also receive Q.250 per day for lodging, per diem, and local transportation. As was the case with the OR study, the supervision phase would be the most costly, followed by the training and then the planning phase. But the supervision phase would be much less costly in the scaling-up scenario because only one person-day of direct supervision would be necessary for each trainee, rather than the two or more days of direct supervision provided during the original intervention.

The planning and design phase consists of a half-day meeting with MSPAS and FRONTIERS staff to introduce the model and make any final adjustments needed to adapt the algorithm for a particular health region. The implementation of training includes a portion of the cost of a "trainer of trainers" workshop ${ }^{18}$, as well as the costs of provider workshops themselves. Under these assumptions, the economic cost per trainee of Q.1,248 (US\$161) is approximately half of the estimated cost per trainee in Quiche, the least expensive of the two regions included in the OR study. The financial cost per trainee, representing actual financial outlays by MSPAS, would be Q.869, or US\$112. 


\section{NOTES}

${ }^{1}$ DHS-Guatemala. Guatemala: Encuesta nacional de salud materno infantil 19981999. Guatemala: INE, MSPAS, USAID, UNICEF, UNFPA, Macro International, 1999.

${ }^{2}$ Policy, Population Council, et al. "Un estudio de barreras médicas en Guatemala." Unpublished report. Ciudad de Guatemala: Population Council, 1999.

${ }^{3}$ MSPAS, INCAP, USAID, UNICEF, and DHS/Macro (1999) Guatemala: Salud materno infantil en los departamentos del altiplano: Encuesta de proveedores de salud 1997. Ciudad de Guatemala, Authors.

${ }^{4}$ MSPAS received PowerPoint presentations of the model and preliminary results of its evaluation in Peru in late 2000. A written report was available in early 2001 (León, F. R. "Introducing a balanced counseling strategy with interactive job aids: Effects on provider's quality of care as measured by the Service Test". Peru PCI-QoC Project Bulletin \# 6. Lima: Population Council, 28 February 2001).

${ }^{5}$ See Ref. 3.

${ }^{6}$ W. Rinehart, S. Rudy, \& M. Drennan, "New GATHER guide to counseling." Population Reports Series J, Number 48, 1998.

${ }^{7}$ M. C. Burkhart, L. de Mazariegos, S. Salazar, and V. M. Lamprecht. "Effectiveness of a standard-rule method of calendar rhythm among Mayan couples in Guatemala.” International Family Planning Perspectives 2000, 26, 3:131-136.

${ }^{8}$ Most hospitals do not offer family planning in outpatient consultations.

${ }^{9}$ National Reproductive Health Guidelines. Guatemala: Ministry of Health and Social Welfare, 2000.

${ }^{10}$ J. Luck and J. W. Peabody. "Using standardized patients to measure physicians' practice: validation study using audio recorders." British Medical Journal 2002, 325: 679 .

${ }^{11}$ F. R. León, A. Ríos, and A. Zumarán. "Improving provider-client interactions at Peru MOH clinics: Extent and cost." Frontiers Final Report. Lima: Population Council, 13 May 2002.

12 Simulated clients enacting Profiles A and B at the same facility requested the services the same day. However, some of them may have been served by different providers. 
${ }^{13}$ Reichardt, C. S. "The statistical analysis of data from nonequivalent group designs." In T. D. Cook and D. T. Campbell, Quasi-Experimentation: Design and Analysis Issues for Field Settings. Chicago: Rand McNally, 1979.

14 The standard calculation of effect size is based on posttest scores, not gain scores (see Lipsey, M. W. Design Sensitivity: Statistical Power for Experimental Research. Newbury Park: Sage, 1990). In the present application, the gain score was treated as an adjusted posttest score.

15 The independent results calculated for Study 1 and Study 2 were nearly identical to the results on the integrated groups analysis, i.e., each of them showed the experimental group to be more than two standard deviations ahead of the control group.

${ }^{16}$ See Ref. 11.

${ }^{17}$ Whereas session length in minutes produced a skewed distribution, the Posttest minus Posttest difference was nearly normally distributed. All the quality of care indicators were normally distributed.

${ }^{18}$ MSPAS would likely train several groups of trainers at once in order to take advantage of economies of scale. We do not know how many groups would be trained, but these calculations assume that only two groups are trained at the workshop. Therefore, half of the cost of the workshop is included in the "Implementation of Training" category. 


\section{APPENDIX 1: JOB AIDS-ASSISTED BALANCED COUNSELING ALGORITHM}

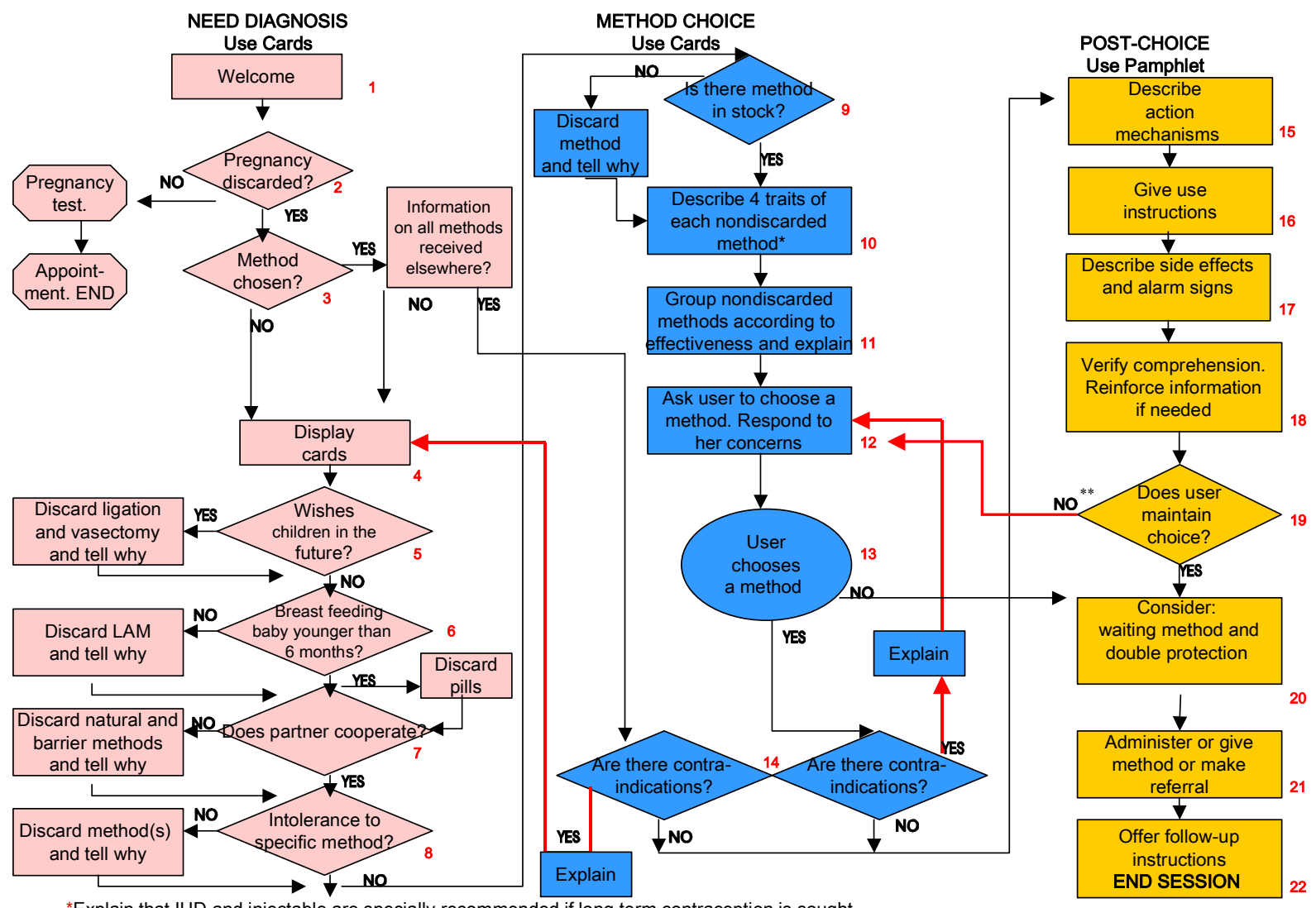

${ }^{*}$ Explain that IUD and injectable are specially recommended if long term contraception is sought ** Display cards if the user came with method already chosen 


\section{APPENDIX 2: METHOD CARDS}

A

\section{INYECCION}

- Es una inyección que se pone cada 3 meses

- Al dejar de ponérsela, algunas mujeres podrían pasar un tiempo. antes de quedar embarazadas.

- Al usarla, en algunas mujeres puede dejar de bajar su menstruación (costumbre), esto es normal.

- Después de seis semanas del parto, la pueden usar las mujeres que están dando pecho.

\section{B NO DEBE OFRECERSE A:}

- Mujeres embarazadas (embarazo posible o confirmado)

- Mujeres con sangrado vagínal no diagnósticado.

- Mujeres que no toleren cambios en su menstruación, especialmente ausencia.

- Mujeres con antecedentes de cáncer de mama 

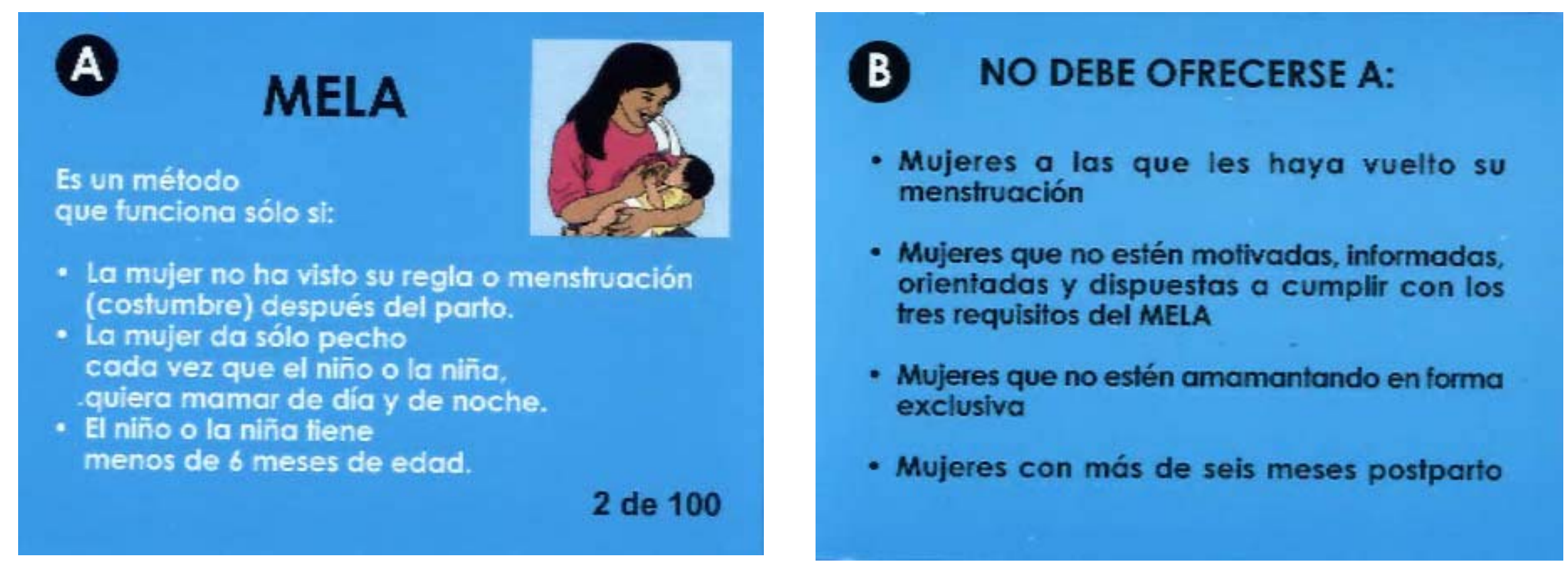


\section{A} T DE COBRE

- Tiene forma de T y está hecha de plástico y recubierta de cobre

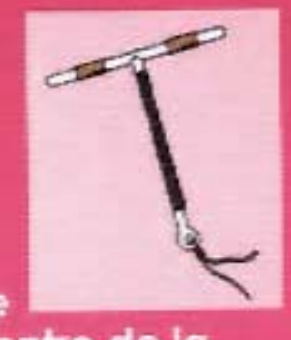

- El personal de salud la coloca dentro de la matriz de la mujer.

- Ofrece hasta 10 años de protección pero el personal de salud la puede refirar cuando la mujer lo desee.

- En los primeros meses de uso, puede causar dolor y aumento en el sangrado durante la regla. (costumbre).

\section{B NO DEBE INSERTARSE A:}

- Mujeres con sangrado vaginal de causa desconocida.

- Cuando la mujer o su pareja tienen varias parejas sexuales.

- Mujer con infección vaginal y del cuello de la matriz.

- Mujeres con infección inflamatoria pélvica activa.

- Mujeres en posaborto o posparto séptico.

- Mujeres con anormalidades uterinas congenitas o tumores en la cavidad uterina.

- Mujeres con embarazo o sospecha

- Estenosis cervical. 


\section{A OPERACIÓN DE LA MUJER}

- Es un método para toda la vida.

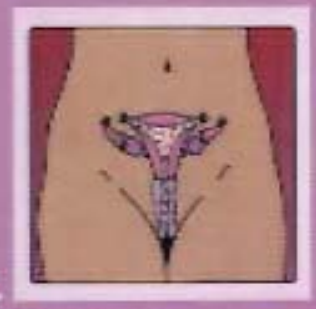

- Es una operación sencilia y muy segura que dura menos de 20 minutos.

- Las relaciones sexuales de la pareja siguen igual y la mujer sigue viendo su menstruación o regla cada mes.

- La mujer puede regresar a su casa el mismo día, entre 2 y 6 horas después de la operación.

\section{B NO DEBE REALIZARSE EN:}

- Mujeres con infecciones pélvicas o generales agudas (hasta que se controlen)

- Mujeres con contraindicaciones para cualquier operación (incluyendo el embarazo)

- Mujeres que no estén seguras del número de hijos que desean tener

- Mujeres que esten pasando por una crisis emocional o inestabilidad con su pareja.

- Mujeres que no den su consentimiento voluntario e informado 
A

\section{CONDON}

- Es una bolsita resistente hecha de un material elástico llamado látex que se pone el hombre en cada relación sexual.

- Es el único método que protege de Infecciones de Transmisión Sexual y VIH-SIDA.

- Se usa uno nuevo para cada relación sexual.

- Se coloca en el pene o miembro del hombre cuando ya está erecto (parado) antes de meterlo en la vagina de la mujer.

10 de 100

\section{B NO DEBE OFRECERSE A:}

- Parejas para las cuales el embarazo puede representar un serio riesgo a la salud de las mujeres.

- Parejas que son alérgicas a los materiales con los que se fabrica el condón (látex) 


\section{A \\ OPERACIÓN DEL HOMBRE}

- Es un método para siempre

- Es una operación sencilla y muy segura que dura menos de 15 minutos.

- Las relaciones sexuales o íntimas de la pareja siguen igual y el hombre siempre saca liquido (semen) pero sin espermatozoides (semilla).

- El hombre puede regresar a su casa el mismo día, entre 2 y 4 horas después de la operceión.

1 de 1000

\section{B NO DEBE OFRECERSE A:}

- Hombres que no estén seguros acerca de sus intenciones reproductivas

- Parejas que no estén seguras del número de hijos que desean tener

- Hombres que no den su consentimiento voluntario e informado 
A

\section{PASTILLA}

- Es una pastilla que la mujer toma fodos los días.

- Las mujeres que están dando de mamar pueden usarla hasta que su hiljo o hija tenga por lo menos 6 meses de edad.

- Cuando la mujer quiere quedar embarazada. sólo tiene que dejar de tomarlas al terminar el sobre.

- Algunas mujeres sienten dolores de cabeza los primeros meses.

4 de 100

\section{B NO DEBE OFRECERSE A:}

- Mujeres embarazadas.

- Sangrado vaginal de causa desconocida.

- Fuma más de 20 cigarrillos diarios y es mayor de 35 años.

- Enfermedad cardíaca, infarto, hipertensión arterial, trastornos de la coagulación.

- Mujeres que no recuerden tomar la pastilla a diario

- Diabetes de más de 20 años y con compromiso vascular

- Cáncer de mama.

- Enfermedad hepática activa (ictericia) 


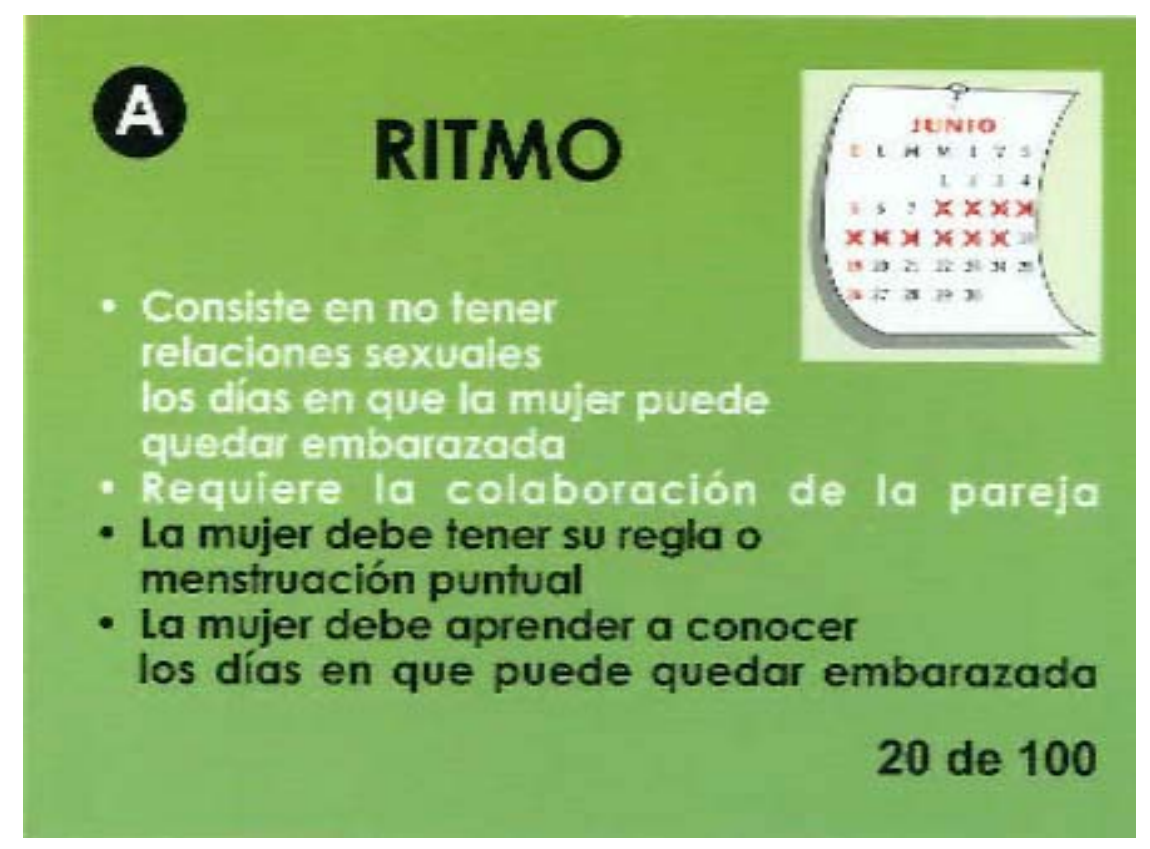

\section{B NO ES UN BUEN MÉTOdO PARA:}

- La mujer que está lactando.

- Parejas para las cuales el embarazo puede representar un serio riesgo a la salud de las mujeres.

- Mujeres con pareja que no está de acuerdo o no desea colaborar

- Mujeres con ciclos menstruales irregulares 
A

A PRUEBA VERBAL DE EMBARAZO

- ¿Empezó su última menstruación en los últimos 7 días?

- ¿Ha evitado tener relaciones sexuales desde su última menstruación?

- ¿Ha estado usando bien un método anticonceptivo?

- ¿Ha tenido una pérdida (aborto) en los últimos 7 días?

- ¿Ha tenido un hijo hace menos de un mes?

- ¿Su hijo nació hace menos de 6 meses y le está dando sólo pecho y usted todavía no ha visto su menstruación?
B

Si la usuaria contesta SI a cualquiera de las preguntas, y no hay signos 0 síntomas de embarazo, usted puede estar seguro que NO esta embarazada. Provea el método. 


\section{APPENDIX 3: EXAMPLE OF METHOD PAMPHLET}

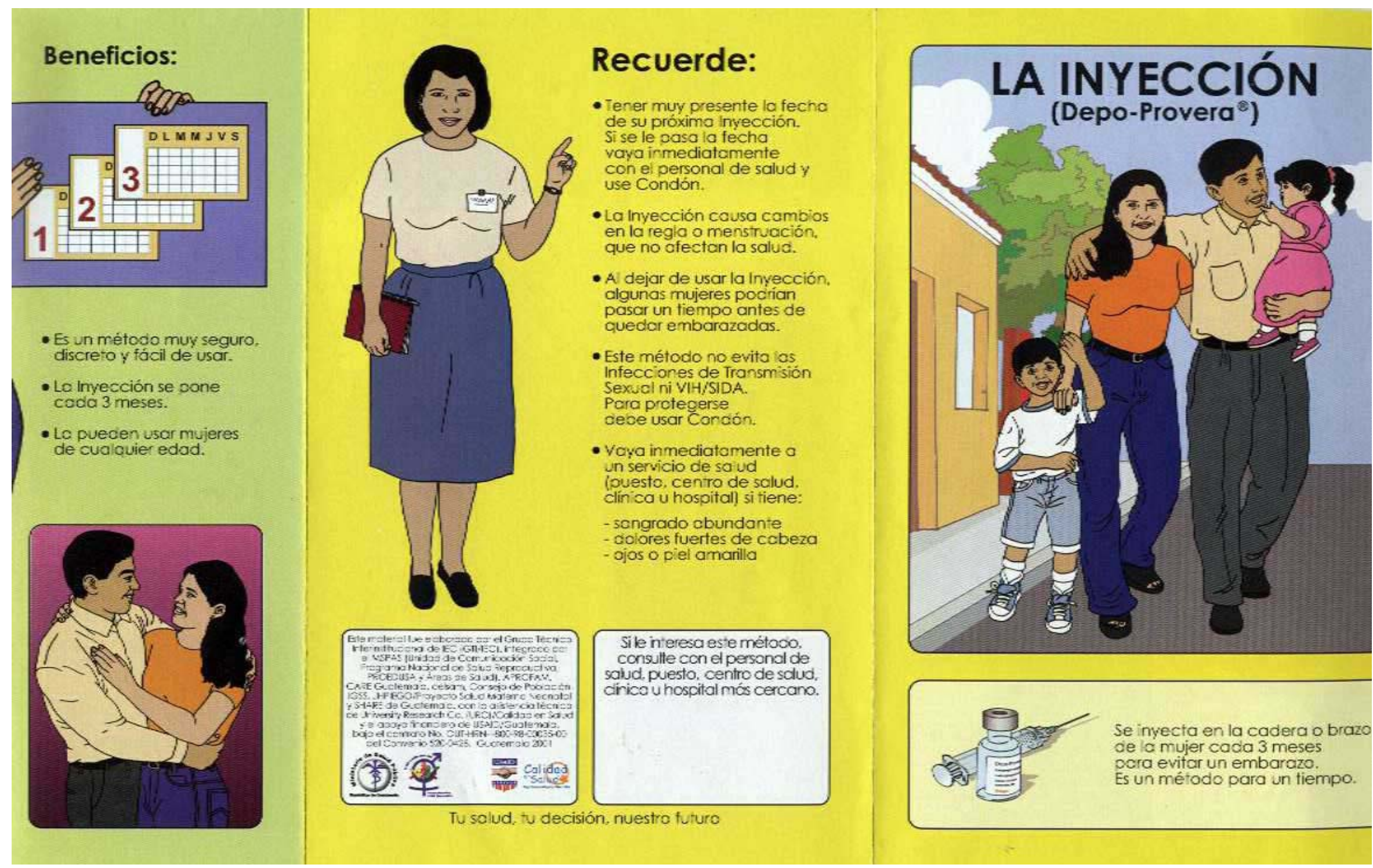

Testing Balanced Counseling to Improve Provider-Client Interaction in Guatemala's MOH Clinics 
¿Quiénes pueden usar la Inyección ¿ Depo-Provera ${ }^{\circledR}$ ?

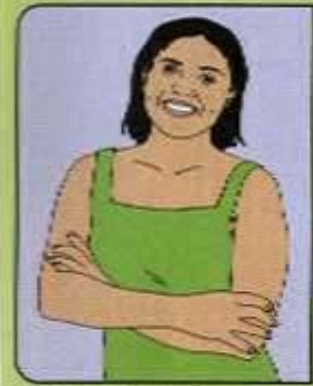

Las mujeres que prefieren escerar

un fiempo ontes de

su primer embcrazo

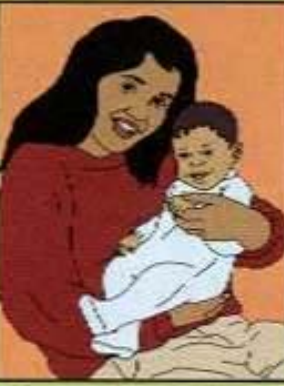

Las mujeres que prefieren dejar pasar un tiempo ente embarazos

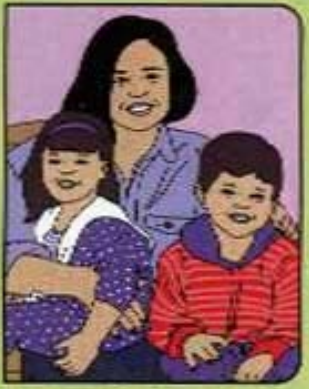

Los mujeres que ya tienen el número ceseado de hijas e hijos y no se han decicido para siempre

¿Cada cuánto y cómo se pone la Inyección?

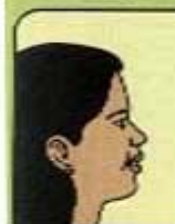

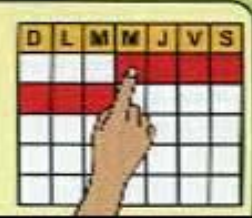

La inyección se pone ccda 3 meses.

Lo orimera vez.

se la pueden poner cuando tienes suralo

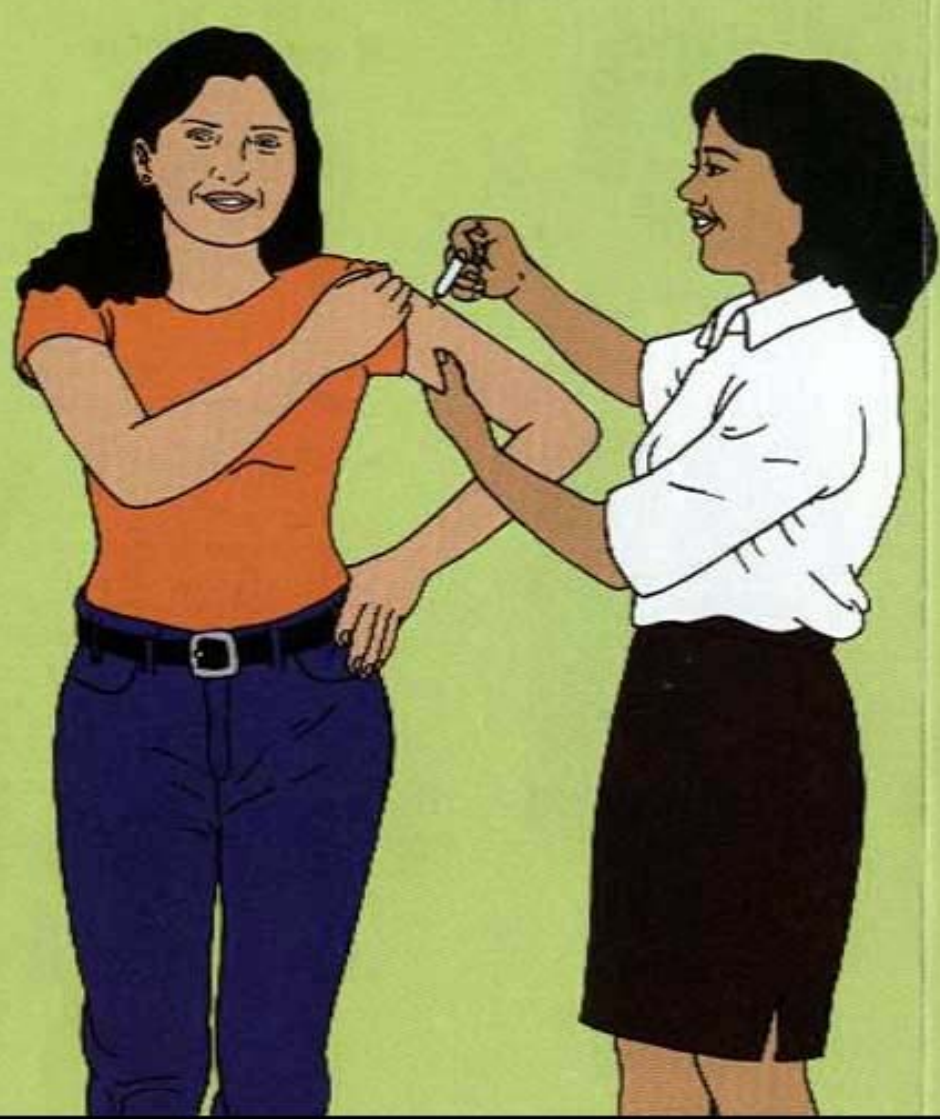

Después de seis semonas del parto, la inyección es un buen método para la mujer que está dando pec

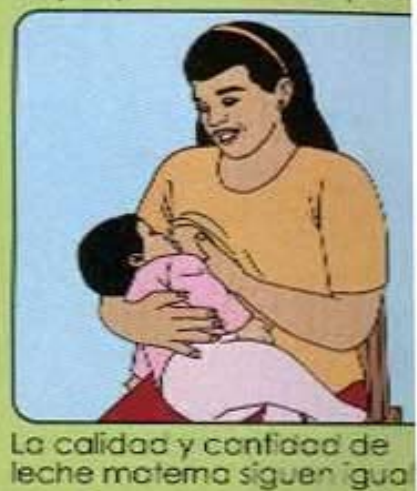

¿Qué más debe saber?

- Con las orimeras dos

invecciones algunas muje dejon de tener su reglo 0 ver manchas de sangre en una menstruación y otra. 